\title{
Cotrimoxasole-Resistant Stenotropomonas maltophilia Infection : Case Report
}

\author{
Dani Rosdiana, ${ }^{1 *}$ Dewi Anggraini ${ }^{2}$
}

\begin{abstract}
Stenotrophomonas maltophilia is an important multidrug-resistant nosocomial pathogen associated with high mortality. This infection did not elucide clearly in Riau. We reported two Cotrimoxaxole Resistant Stenotrophomonas maltophilia in patient of Arifin Achmad Hospital which refered from peripheral hospital in another region. They had similar clinical appereance such as long stay hospitalization, bad clinical appearance and had a history of meropenem exposure before. We performed urin culture to make appropriate diagnostic and treatment also. Stenotrophomonas maltophilia bacteria was found in urine isolate. The sensitivity test showed that this bacteria had Cotrimoxasole resistant that standard antibiotic of this bacteria. The management of these cases become complicated due to decrease of renal function in one patient. We had to make dose adjustment of parenteral levofloxacin, giving good nutrition, counted fluid balance and repaired others clinical conditions.Beside of its high mortality and morbidity, the outcomes of both these patients were good.
\end{abstract}

Keywords: Stenotrophomonas maltophilia, multidrug resistant, levofloxacin, insufisiensi renal.

Stenotrophomonas maltophilia pertama kali diisolasi pada tahun 1943 sebagai Bacterium bookeri, kemudian diubah namanya menjadi Pseudomonas maltophilia pada tahun 1961 dan selanjutnya diberi nama menjadi Xanthomonas maltophilia pada tahun 1983 berdasarkan analisa ribosoma RNA. Analisis lebih jauh membuktikan bahwa organisme ini memiliki genus sendiri dan akhirnya diberi nama Stenotrophomonas maltophilia pada tahun 1993. Pengetahuan mengenai bakteri ini tergolong masih baru. Sebenarnya kuman ini bukan merupakan kuman yang sangat patogen, tetapi bakteri ini telah menjadi patogen nosokomial yang penting dengan mortalitas hingga mencapai $69 \%$ jika terjadi bakteriemia. ${ }^{1}$ Bakteri ini menjadi opportunis yang dapat menginfeksi pasien immunocompromised. Pada pasien sehat yang mendapat alat medis invasif yang terkontaminasi seperti teknologi dialisa, intubasi, alatalat implant atau alat medis yang lain yang

\footnotetext{
* Penulis untuk korespondensi : dr.danirosdiana123@ gmail.com

1 KJF/KSM Ilmu Penyakit Dalam RSUD Arifin Achmad Provinsi Riau/ FK Universitas Riau.

2 KJF Mikrobiologi FK Universitas Riau.
}

terkolonisasi oleh bakteri, berkontribusi pada infeksi ini. $^{2}$

Beberapa karakteristik Stenotrophomonas maltophilia antara lain: merupakan kuman gram negatif, non fermentasi, banyak tersebar pada lingkungan di semua distribusi geografis terutama di air. memiliki kemampuan membentuk biofilm pada permukaan peralatan seperti kaca, plastic, teflon dan juga jaringan pejamu termasuk sel-sel paru. ${ }^{1,3}$ Kuman ini umumnya ditemukan pada infeksi saluran pernapasan, faktor-faktor risiko yang meningkatkan angka kematian antara lain gagal organ, syok septik berat, dan keganasan. Selain itu, infeksi Stenotrophomonas maltophilia ini juga ditemukan pada pasien-pasien dengan keganasan atau pasien yang dirawat di rumah sakit dalam periode lama. ${ }^{4}$

Stenotrophomonas maltophilia, seperti kuman patogen penyebab nosokomial yang lain, juga sering mengakibatkan resistensi terhadap beberapa kelas antibiotik. Resistensi antibiotik lebih sering ditemukan pada isolat klinik dibandingkan dengan isolat dari lingkungan dan bahkan telah ditemukan bahwa kuman ini juga resisten dengan golongan kotrimoksasol yang dikaitkan dengan adanya gen sul1. ${ }^{4}$ Data mengenai infeksi Stenotrophomonas 
maltophilia belum banyak dilaporkan. Begitu juga di Riau, infeksi ini cukup jarang dilaporkan, namun karena morbiditas dan mortalitasnya yang tinggi jika terjadi bakterimia, sehingga penting untuk dibahas dan dipelajari terutama tentang deteksi faktor risiko serta penatalaksanaannya.

\section{PRESENTASI KASUS}

\section{Kasus 1.}

Seorang lak-laki 19 tahun dengan keluhan nyeri seluruh abdomen terutama saat buang air kecil dirasakan sejak 1 bulan terakhir sebelum masuk RS di Kabupaten Rohul. Pasien dirawat selama 1 minggu sebelum akhirnya dirujuk ke RSUD Arifin Achmad karena gagal ginjal dan anemia. Keluhan nyeri abdomen terutama di daerah suprapubik, nyeri seperti kolik, disertai dengan demam, buang air kecil merah seperti cucian daging. Berat badan pasien turun dan juga pasien tidak mau makan (low intake). Pasien diberikan antibiotik meropenem 1 gram per 12 jam, karena kondisi pasien semakin menurun kemudian dirujuk. Sebelumnya pasien tidak pernah sakit apapun.

Hasil pemeriksaan fisik menunjukkan pasien tampak lemah, conjungtiva pucat, demam $\left(39^{\circ} \mathrm{C}\right)$, tekanan darah 130/90 mmHg nadi 110x/menit, frekuensi pernapasan: $28 \mathrm{x} /$ menit pasien tampak kurus, pemeriksaan paru dan jantung dalam batas normal. Pemeriksaan abdomen : supel, ascites minimal, hepatomegali dan splenomegali tidak ditemukan, nyeri tekan di regio supra pubis $(+)$. Pemeriksaan penunjang ditemukan leukosit 25.450/ $\mathrm{mm}^{3}$, Hb $6.1 \mathrm{mg} / \mathrm{dl}$, fungsi hati SGOT/SGPT: 20/22, fungsi ginjal ureum/creatinin: 235/6,7. Asam urat 9.9 $\mathrm{mg} / \mathrm{dl}$, albumin $2,5 \mathrm{mg} / \mathrm{dl}$. USG abdomen: hidronefrosis bilateral grade 4 dan disffuse parenchymal renal diseases bilateral. Kultur urine: Stenotrophomonas maltophilia dengan tes sensitivitas ternyata resisten dengan semua antibiotik termasuk kotrimoksazol. Pasien didiagnosis dengan urosepsis akibat Stenotrophomonas maltophilia dengan pemberat anemia.

Pasien ditatalaksana untuk mengoreksi anemia dengan pemberian pack red cell sebanyak 1200 cc karena pasien juga mengalami hematuria selama dirawat, kemudian pasien dilakukan monitoring ketat keseimbangan cairan intake dan outputnya. Pasien tidak diberikan hemodialisa karena diuresis masih lebih dari 1000 cc/24 jam dan tidak ditemukan sindroma uremia selama dirawat. Urosepsis diterapi dengan meropenem $2 \times 1$ gram iv sambil menunggu hasil kultur. Setelah kultur urin keluar, pasien diberikan levofloksasin $750 \mathrm{mg}$ iv per 36 jam, sesuai dengan hasil diskusi dengan mikrobiologi klinik karena secara invitro kuman telah resisten dengan semua kelas antibiotik. Anemia membaik pada hari ke 18 dirawat (Hb;10,7 mg/dl) dan fungsi ginjal membaik $\mathrm{Ur} / \mathrm{Cr}$ : 69/2,53 mg/dl). Infus levofloksasin dihentikan setelah 9 hari pemberian karena klinis membaik dan leukosit sudah membaik $\left(13,4 / \mathrm{mm}^{3}\right)$. Etiologi hidronefrosis juga terus digali karena ingin mengobati etiologinya di samping mengatasi urosepsisnya. Pemeriksaan CT scan abdomen dilakukan tanpa kontras (karena insufisiensi renal) ternyata didapatkan vesikolitiasis dengan ukuran 7,8 cm seperti terlihat pada gambar 1. Selanjutnya pasien menjalani operasi sectio alta pada tgl 28 Oktober 2017 (hari ke 20 dirawat) ditemukan batu buli seperti gambar 2. Pasien dipulangkan dalam keadaan baik, dan buang air bersih jernih.

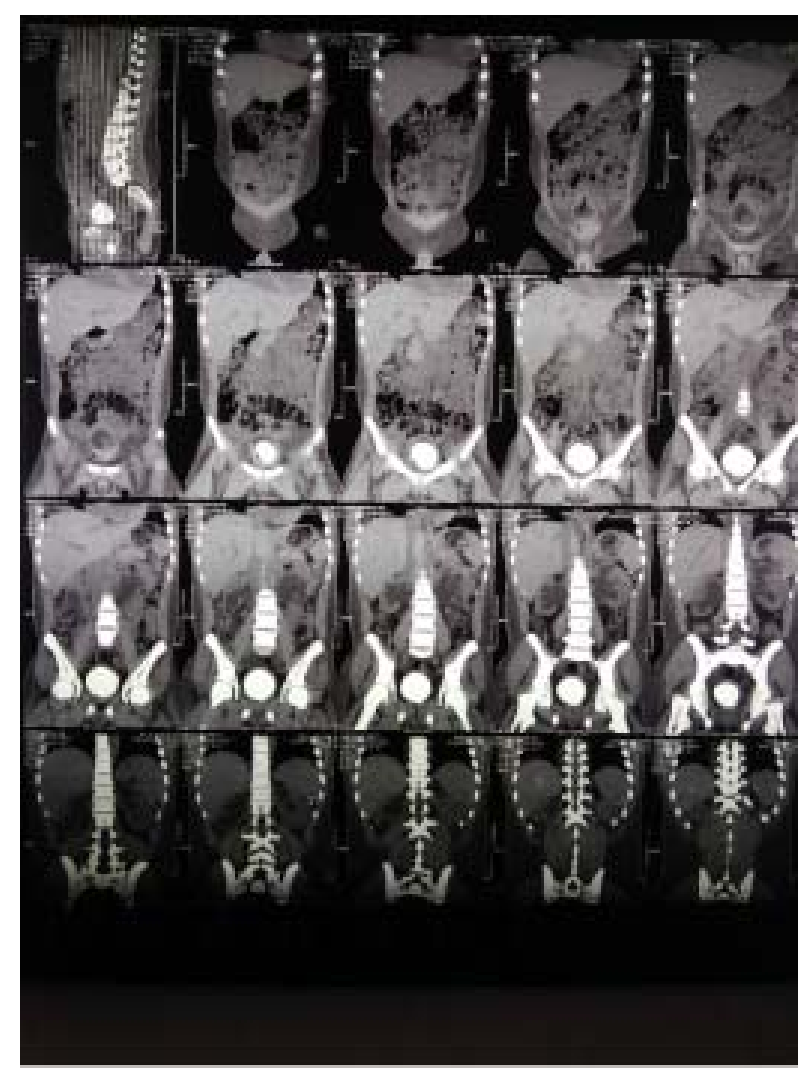

Gambar 1. CT scan abdomen tampak batu buli 


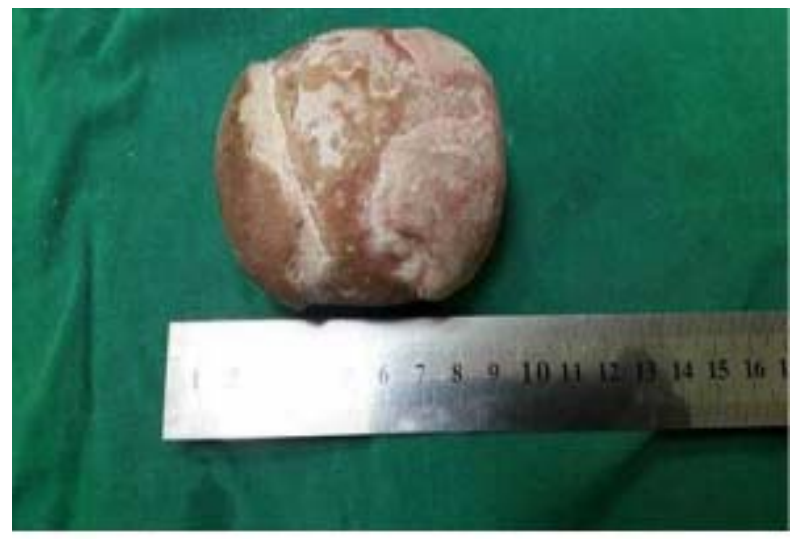

Gambar 2. Ukuran batu buli (hasil operasi)

\section{Kasus 2.}

Seorang laki-laki, 41 tahun datang ke UGD dengan keluhan badan lemas sejak 3 hari terakhir. Pasien sebelumnya mengeluh demam 5 hari yang lalu, disertai menggigil, terus menerus, mual, muntah dan tidak ada nafsu makan. Pasien kurang minum. Pasien juga ada riwayat diabetes melitus 5 tahun tidak terkontrol. Pasien sudah dirawat di RS Kabupaten $\mathrm{X}$ dan sudah diberikan antibiotik meropenem.

Hasil pemeriksaan fisik menunjukkan pasien tampak lemah, konjungtiva tidak pucat, demam $\left(39,9^{\circ} \mathrm{C}\right)$, tekanan darah $130 / 90 \mathrm{mmHg}$ nadi $120 \mathrm{x} /$ menit, frekuensi pernapasan 20x/menit. Pemeriksaan paru dan jantung dalam batas normal. Pemeriksaan abdomen supel, ascites minimal, hepatomegali dan splenomegali tidak ditemukan, nyeri tekan di regio supra pubis (+). Pemeriksaan penunjang ditemukan gula darah sewaktu $346 \mathrm{mg} / \mathrm{dl}$. Leukosit 19.360/ $\mathrm{mm}^{3}$ $\mathrm{Hb}$ 12,2 mg/dl, fungsi hati: SGOT/SGPT: 17/23, fungsi ginjal $=$ ureum $/ \mathrm{kreatinin} 20 / 0,62$. Asam urat 9,9 mg/dl, albumin 2,5 mg/dl. Na: 118, K: 3,04, Cl: $80,8 \mathrm{mmol} / \mathrm{L}$. USG abdomen: ascites, nefrokalsinosis renal bilateral disertai peningkatan echo struktur renal, sistitis dan pembesaran prostat, dari kultur urin didapatkan Stenotrophomonas maltophilia dengan hasil uji sensitivitas resisten dengan kotrimoksazol (uji resistensi untuk Stenotrophomonas maltophilia hanya terstandar untuk antibiotik trimetropim/ sulfametoksazol saja). Berdasarkan literatur, levofloksasin atau amoksisilin/ asam klavulanat dapat dijadikan pilihan terapi bakteri ini. Pasien didiagnosis dengan urosepsis akibat Stenotrophomonas maltophilia dengan pemberat anemia.
Pasien diterapi dengan ciprofloksasin 2 x 400 gram iv sebagai terapi empirik sambil menunggu hasil kultur. Setelah kultur urin keluar, pasien diberikan levofloksasin $750 \mathrm{mg}$ iv per 24 jam, berdasarkan hasil diskusi dengan dokter mikrobiologi klinik karena secara in vitro kuman telah resisten dengan kotrimoksazol. Hiponatremi berat dikoreksi dengan pemberian $\mathrm{NaCl} 3 \%$ dan intake oral. Pasien ini memiliki komorbid DM, sehingga kontrol glukosa mutlak dilakukan. Pasien diberikan insulin short acting kerja cepat 12 unit subkutan.

Luaran setelah koreksi didapatkan kadar elektrolitnya Na: 136,6, K: 3.29, Cl: 95,5 mmol/L. Setelah pemberian antibiotik 5 hari didapatkan leukosit sudah membaik $(9.400 / \mathrm{mm} 3)$. Kadar gula darah terkontrol dibawah $200 \mathrm{mg} / \mathrm{dl}$. Pasien dipulangkan dalam keadaan baik.

\section{PEMBAHASAN}

Penyakit infeksi masih merupakan salah satu masalah kesehatan yang mengancam di negara berkembang termasuk Indonesia. Berbagai infeksi masih mengancam, bahkan tercatat di RSUD Arifin Achmad Pekanbaru penyakit infeksi masuk dalam 10 besar penyakit. Antibiotik merupakan obat yang paling banyak digunakan untuk mengatasi permasalahan ini. Seiring dengan peningkatan penggunaan antibiotik, kejadian resistensi terhadap antibiotik terus meningkat, dari resistensi tunggal hingga resistensi ganda (multidrug resistant). ${ }^{5}$ Sejak pertama penggunaan antimikroba, beban resistensi bakteri terus meningkat terutama dalam 10 tahun terakhir. Secara mengejutkan penicillinase production pada Staphylococcus aureus juga meningkat dengan cepat sejak tahun $1940 .{ }^{6}$

Resistensi adalah kemampuan bakteri untuk menetralisir dan melemahkan daya kerja antibiotik. Hal ini dapat terjadi dengan beberapa cara, yaitu: 1) Merusak antibiotik dengan enzim yang diproduksi. 2) Mengubah reseptor titik tangkap antibiotik. 3) Mengubah fisiko-kimiawi target sasaran antibiotik pada sel bakteri. 4) Antibiotik tidak dapat menembus dinding sel, akibat perubahan sifat dinding sel bakteri. 5) Antibiotik masuk ke dalam sel bakteri, namun segera dikeluarkan dari dalam sel melalui mekanisme transport aktif ke luar sel. ${ }^{7}$ Kejadian resistensi bahkan multiresisten meningkat dengan dua 
mekanisme yaitu selective pressure dan penyebaran resistensi ke bakteri non resisten. Mekanisme selective pressure terjadi jika bakteri resisten tersebut mengalami duplikasi setiap 20-30 menit (untuk bakteri yang berbiak cepat), maka dalam 1-2 hari, seseorang tersebut dipenuhi oleh bakteri resisten. Penyebaran resistensi ke bakteri yang nonresisten melalui plasmid. Hal ini dapat disebarkan antar kuman sekelompok maupun dari satu orang ke orang lain. ${ }^{8}$ Kedua kasus yang dilaporkan kali ini, keduanya memiliki riwayat pemakaian antibiotik lebih dari satu minggu dari golongan karbapenem yang dapat memicu kejadian selective pressure. Sebuah laporan kasus dari Tsiodras menyebutkan bahwa dari 69 kasus kotrimoksazol resisten Stenotrophomonas maltophilia, 99\% memiliki riwayat paparan antibiotik sebelumnya. Sebanyak 58\% infeksi Stenotrophomonas maltophilia mengenai saluran pernapasan, sementara dua kasus yang kami laporkan mengenai saluran kemih. ${ }^{9}$ Jenis antibiotik yang sering diberikan sebagai pemicu kotrimoksazol resisten Stenotrophomonas maltophilia ini adalah jenis cefotetan, kloramphenikol dan ticarcillinclavulanate, sementara kedua kasus yang kami laporkan terdapat riwayat paparan meropenem.

Telah dijelaskan sebelumnya bahwa faktor risiko yang memicu infeksi Stenotrophomonas maltophilia antara lain: keganasan, pemakaian alat invasif yang terkontaminasi bakteri ini, immunocompromised, kegagalan organ, maka terbukti memang kedua pasien ini memiliki faktorfaktor risiko tersebut yaitu pasien pertama terpasang kateter urin karena hematuria, rawat lama serta gagal ginjal. Sementara pasien Y memiliki diabetes melitus yang dapat menyebabkan keadaan immunocompromised. Dubois dalam artikelnya menyebutkan bahwa pasien dengan intoleransi glukosa memiliki risiko terinfeksi Stenotrophomonas maltophilia karena kemungkinan mudahnya terkena penyakit paru fibrosis. ${ }^{10}$

Beberapa kuman resisten antibiotik sudah banyak ditemukan di seluruh dunia antara lain: Methicillin-Resistant Staphylococcus aureus (MRSA), Vancomycin Resistant Enterococci (VRE), Penicillin-Resistant Pneumococci, Klebsiella pneumoniae yang menghasilkan Extended-Spectrum Beta-Lactamase (ESBL), Carbapenem-Resistant Acinetobacter baumannii dan Multiresistant Mycobacterium tuberculosis. ${ }^{8}$ Cotrimoksasole Resistant Stenotrophomonas maltophilia belum banyak disinggung karena kejadiannya masih jarang.

Terapi Stenotrophomonas maltophilia menjadi sulit karena kuman ini secara inheriten resisten tehadap beberapa kelas antibiotik termasuk â-lactam dan aminoglikosida. Antibiotik yang secara in vitro dapat melawan Stenotrophomonas maltophilia adalah trimethoprimsulfamethoxazole (SXT), ûuoroquinolones (FQs), tetracyclines, ticarcillin-clavulanate, dan ceftazidime. Menurut Wang, diantara kelas antibiotik tersebut, monoterapi dengan Fluoroquinolone dan SXT sama efektif untuk mengobati infeksi Stenotrophomonas maltophilia. ${ }^{11}$ Penelitian lain yang membandingkan keefektifan pengobatan antibiotik tunggal atau kombinasi memperlihatkan bahwa kombinasi antara SXT + FQ secara statistik Stenotrophomonas maltophilia tidak signifikan keefektifannya dalam ketahanan 30 hari (30-day survival rates), namun secara mikrobiologi memberikan banyak manfaat. Pemberian antibiotik kombinasi berbasis SXT direkomendasikan terutama pada kasus dengan infeksi Stenotrophomonas maltophilia yang berat. ${ }^{12}$

Pada kedua pasien yang kami laporkan ternyata keduanya secara in vitro mengalami resistensi terhadap SXT, padahal kita tahu bahwa SXT merupakan terapi antibiotik standar untuk Stenotrophomonas maltophilia. Sehingga kami memberikan levofloxacin yang secara in vitro cukup efektif dalam melawan Stenotrophomonas maltophilia. Pada kasus-kasus ini levofloksasin cukup berhasil, secara klinis maupun laboratoris pasien membaik dan urosepsis pada pasien $\mathrm{X}$ membaik di hari ke 9 pemberian levofloksasin. Karena pasien $\mathrm{X}$ sudah mengalami insufisiensi renal maka kita harus melakukan penyesuian dosis dan pemberiannya. Pemberian levofloksasin bukan merupakan kontraindikasi pada keadaan gangguan ginjal jika memang tidak ada pilihan lain yang lebih efektif. Perlu dipertimbangkan karena ekskresi levofloksasin melalui ginjal, maka dengan adanya insufisiensi renal, maka lamanya ekskresi bisa lebih lama, sehingga pada pasien ini levoflosasin $750 \mathrm{mg}$ diberikan setiap 36 jam sekali. ${ }^{13}$ 


\section{SIMPULAN}

Laporan kasus ini didapatkan gambaran bahwa infeksi Stenotrophomonas maltophilia sudah mulai ditemukan di Provinsi Riau. Pada pasien dengan riwayat faktor risiko infeksi Stenotrophomonas maltophilia hendaknya waspada dan melakukan pemeriksaan kultur dan uji sensitivitas, karena tampilan klinis infeksi bakteri nosokomial serupa dan biasanya sudah resisten dengan beberapa kelas antibiotik. Pemberian levofloksasin cukup baik pada infeksi Stenotrophomonas maltophilia resisten kotrimoksazol.

\section{DAFTAR PUSTAKA}

1. Prinsloo B. Stenotrophomonas maltophilia. Lancet Lab. 2016:2:1

2. Sun E, Liang G, Wang L, Wei W, Lei M, Song S. et al. Antimicrobial susceptibility of hospital acquired Stenotrophomonas maltophilia isolate biofilms. Braz j infect dis. 2016;20(4):365-373

3. Flores TS, Gutie'rrez FJ, Morf'ýn OR, Rodr' iguez $\mathrm{N}$, Rivadeneyra DE, Rivas MC. Stenotrophomonas maltophilia in Mexico: antimicrobial resistance, biofilm formation and clonal diversity. Journal of Medical Microbiology.2014:63:1524-1530. DOI 10.1099/ jmm.0.074385-0.

4. Paopradit P, Srinitiwarawong K, Ingviya N, Singkhamanan K, Vuddhakul V. Distribution and characterization of Stenotrophomonas maltophilia isolates from environmental and clinical samples in Thailand. J Hosp Inf. 2017;97(2):185-191. doi: 10.1016/ j.jhin.2017.06.006.

5. Centers for Disease Control and Prevention US Department of Health and Human Services. Antibiotic Resistance Threats in the United States, 2013. (Online) 2013. https:// www.cdc.gov/drugresistance/pdf/ar-threats2013-508.pdf. [diakses tanggal 10 Oktober 2016].

6. Hawkey PM. The growing burden of antimicrobial resistance. Journal of Antimicrobial Chemotherapy (2008) 62, Suppl. 1, i1-i9 doi:10.1093/jac/dkn241.
7. Drilica K, Perlin DS. Antibiotic resistance: understanding and responding to an emerging crisis. Emerging Infectious Diseases. 2011; 17(10): 1984. DOI: http://dx.doi.org/10.3201/ eid1710.111066

8. Menteri Kesehatan Republik Indonesia. Peraturan Menteri Kesehatan Nomor: 2406/ MENKES/PER/XII/2011 tentang pedoman umum penggunaan antibiotik. Jakarta: Departemen Kesehatan. 2011.

9. Tsiodras S, Pittet D, Eliopoulos G, Boucher H, Harbarth S. Clinical implications of Stenotrophomonas maltophilia resistant to trimethoprim-sulfamethoxazole: a study of 69 patients at 2 university hospitals. Scandinaian Journal of Infectious diseases. 2000:32:651-656.

10.Dubois CL, boudreau V, Tremblay F, Lavoie A, Berthiaume Y, Rabasa-Lhoret R. Association between glucose intolerance and bacterial colonization in an adult population with cystic fibrosis, emergence of Stenotrophomonas maltophilia. J Cyst Fibrous. 2017:01.018.

11. Wang YL, Scipione MR, Dubrovskaya Y, Papadopoulos J. Monotherapy with fluoroquinolone or trimethoprim-sulfamethoxazole for treatment of Stenotrophomonas maltophilia Infection. Antimicrobial Agents and Chemotherapy Journal. 2014;58(1):176-182.

12. Hideki A, Baba M, Okada, Abe M, Kimura M, Yoneyama K. Evaluation of trimethoprimsulfamethoxazole based combination therapy against Stenotrophomonas maltophilia: in vitro effects and clinical efficacy in cancer patients. International Journal of Infectious disease. 2017;58:18-21

13.Czock D, Hu“sig-Linde C, Langhoff A, Scho“pke T, Hafer C, de Groot K et all. Pharmacokinetics of moxifloxacin and levofloxacin in intensive care unit patients who have acute renal failure and undergo extended daily dialysis. Clin J Am Soc Nephrol 1. 2006: 1263-1268. doi: 10.2215/ CJN.01840506 